\title{
Analysis on tool life and surface characteristic in milling Stavax Supreme material
}

\begin{abstract}
Stavax Supreme material is classified as difficult-to-machine material. The difficulty does not preclude the use of this material, especially in the mold industry. In this experiment, high speed end milling of Stavax Supreme $(52 \mathrm{HRC})$ was investigated using five different types of tool. Performance of the cutting tools was compared with respect to tool life and surface roughness of the workpiece. Machining process was conducted in two parameters where each parameter used different rotation spindle speed and feed rate but same chip per tooth removal rate. The best cutting performance was obtained with TiN and TiCN. TiAlN tool also proved to be suitable for high speed end milling of Stavax Supreme but for finishing process only because fast tool wear in high spindle speed. The Xceed coated tool is more suitable for roughing process only in high spindle speed.
\end{abstract}

Keyword: High speed machining; Machining hard materials; Stavax 